\title{
TaqMan PCR assay for detection and quantification of Stagonosporopsis tanaceti in pyrethrum seed and seedlings
}

\author{
M. A. H. B. Bhuiyan ${ }^{a}$, T. Groom ${ }^{b}$, M. E. Nicolas ${ }^{a}$ and P. W. J. Taylor ${ }^{a^{*}}$

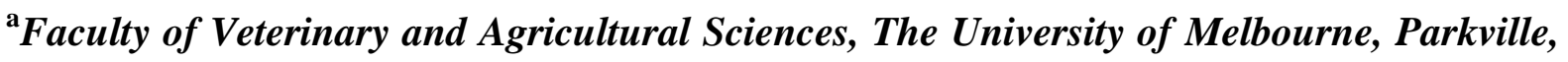 \\ Victoria-3010; ${ }^{\mathrm{b}}$ Botanical Resources Australia-Agricultural Services Pty. Ltd, Ulverstone, \\ Tasmania
}

*Email: paulwjt@unimelb.edu.au

\begin{abstract}
Pyrethrum seed has an important role in the transmission of Stagonosporopsis tanaceti, the cause of ray blight disease of pyrethrum. A TaqMan probe based polymerase chain reaction (PCR) assay was developed to quantify the level of $S$. tanaceti inocula in pyrethrum seed and seedlings. Primer pair (St_qF3, St_qR2) was designed based on the intergenic spacer (IGS) region of $S$. tanaceti, which produced a 125 bp amplicon specific to $S$. tanaceti. TaqMan PCR assay using St_qF3, St_qR2 and a probe was highly specific against the genomic DNA of $S$. tanaceti, but did not amplify DNA of 14 related Stagonosporopsis species or other foliar pathogens of pyrethrum. The sensitivity limit of this assay was measured using the cycle threshold $\left(\mathrm{C}_{\mathrm{t}}\right)$ value which ranged from 17.59 for 10 nanograms (ng) to 36.34 for 100 femtograms (fg) genomic DNA of $S$. tanaceti. There was a significant negative correlation $(\mathrm{r}=-0.999, P<0.001)$ between the $\mathrm{C}_{\mathrm{t}}$ value and the percent of $S$. tanaceti infected seed. In addition, this TaqMan PCR assay detected latent infection within seedlings. This assay could be applied to test commercial seed and seedlings before deciding on the appropriate management practices.
\end{abstract}

Key words: TaqMan PCR, pyrethrum, S. tanaceti, ray blight, intergenic spacer (IGS) region 


\section{Introduction}

Pyrethrum (Tanacetum cinerariifolium) is grown commercially in the states of Tasmania and Victoria of Australia in order to extract insecticidal esters known as pyrethrins, which predominantly occur in the secretory ducts and oil glands of the seed (Bhuiyan et al. 2015). Stagonosporopsis tanaceti (syn. Phoma ligulicola var. inoxydabilis) is the causal agent of ray blight disease, which is considered as one of the major foliar diseases of perennial pyrethrum (Vaghefi et al. 2012, 2016b; Bhuiyan et al. 2017a). This pathogen also infects the crown, petioles, flower stems, flower buds, seed and seedlings of pyrethrum (Bhuiyan et al. 2017a). Other susceptible hosts in Australia include French marigold (Tagetes patula) and chrysanthemum (Chrysanthemum carinatum) (Pethybridge et al. 2008a). Two other ray blight pathogens, S. chrysanthemi and S. inoxydabilis have also been shown to infect pyrethrum seedlings in vitro, however, these pathogens have yet to be found in Australia (Vaghefi et al. 2016a).

Pyrethrum seed is considered a major carrier of S. tanaceti (Bhuiyan et al. 2017b) although infected seed do not show obvious necrotic symptoms or morphological abnormalities. Seedlings with low levels of infection of $S$. tanaceti that develop from infected seed do not have symptoms and are difficult to differentiate from healthy seedlings (Bhuiyan et al. 2017b).

Culturing pyrethrum seed on biological media has been used to determine the infection level of $S$. tanaceti in commercial seed lots (Bhuiyan et al. 2017b). However, culturing methods are time consuming and not effective in discriminating closely related fungal species. Molecular detection assays are species specific and have been used to identify closely related species (Mancini et al. 2016). Polymerase chain reaction (PCR) based molecular detection assay is based on the genotype of an organism, therefore the detection is precise, rapid, 
sensitive and not affected by the environment (Luo and Mitchell 2002). A PCR-based molecular detection assay based on primers of the ITS gene sequence of $S$. tanaceti was developed by Pethybridge et al. (2006) to detect the ray blight pathogen of pyrethrum in Australia. However, the ITS sequence was too conserved to discriminate $S$. tanaceti from the closely related ray blight pathogen $S$. chrysanthemi (Vaghefi et al. 2016b). Vaghefi et al. (2016a) used variable sequences in the intergenic spacer (IGS) region of the ray blight pathogens to design PCR primers to differentiate these species. These species-specific primers were incorporated into a multiplex PCR assay (Vaghefi et al. 2016b). The gene sequences in the IGS region were more diverse than the ITS sequence (Liew et al. 1998; Chilvers et al. 2007; Vaghefi et al. 2016a). Multiple copies of the IGS region in many organisms were homogenised through the steps of concerted evolution (Hillis and Dixon 1991). Besides ITS and IGS genes, other genes such as the actin region have been used to delineate the Stagonosporopsis species of S. andigena and S. crystalliniformis (De Gruyter et al. 2012). However, there are only limited numbers of consecutive nucleotides differences within the actin gene of this genus making Actin gene unsuitable for discriminating closely related species (Vaghefi et al. 2016a).

Compared to conventional PCR, TaqMan PCR assay is less time-consuming and highly sensitive (Mancini et al. 2016) and has been used to quantify specific DNA targets (Ward et al. 2004). Moreover, TaqMan PCR has a much lower possibility of a false positive reaction in a cross-reaction mixture than conventional PCR (Tomlinson et al. 2005).

Assay techniques to detect and quantify $S$. tanaceti infection levels within pyrethrum plant tissues are limited. Therefore, the objective of this study was to develop a TaqMan probe based PCR assay using primers specific to the IGS region to detect and quantify S. tanaceti infection in pyrethrum seed and seedlings. 


\section{Materials and Methods}

\section{Genomic DNA of Stagonosporopsis species and other foliar fungal pathogens of pyrethrum}

Genomic DNA was extracted from isolates UMSt5 (TAS 1) and UMSt6 (TAS 55503) of Stagonosporopsis tanaceti recovered from infected pyrethrum plants in Tasmania as described by Vaghefi et al. (2016a). Genomic DNA of 14 Stagonosporopsis species, derived from reference cultures were obtained from the culture collection of Centraalbureau voor Schimmelcultures (CBS), The Netherlands (Table 1). In addition, the genomic DNA of a Victorian isolate of S. tanaceti (UMSt 1), and foliar pathogens of pyrethrum Alternaria infectoria (UMAi01 BRIP65180), Stemphylium herbarum (UMSh02 BRIP65181), Colletotrichum tanaceti (BRIP57314), Didymella tanaceti (UMDt 1), Pestalotiopsis sp. (UMPes 1), Paraphoma vinacea (UMPv001 BRIP63684), Pa. chlamydocopiosa (UMPco1 BRIP65168) and Pa. pye (UMPp02 BRIP65169) were obtained from the culture collection of the Faculty of Veterinary and Agricultural Sciences, the University of Melbourne, Parkville, Victoria.

\section{TaqMan PCR primer design and validation}

The sequence of the IGS region $(\sim 3 \mathrm{~kb})$ of nuclear ribosomal DNA of $S$. tanaceti was obtained from the GenBank accession number KP161044 (Vaghefi et al. 2016a). A variable region within the IGS, downstream of the $28 \mathrm{~S}$ rDNA was targeted to design nine primer pairs and a probe sequence (Table 2) using Primer3 software (Rozen and Skaletsky 1999) for the purpose of developing a TaqMan PCR assay. The primer pairs and probe were checked for their specificity using BLAST search against NCBI GenBank to avoid the possibility of nonspecific priming. Then the primers were synthesised by Sigma-Aldrich (Castle Hill, New South Wales, Australia) and the probe by Life Technologies Australia Pty Ltd (Mulgrave, Victoria, Australia). 
The amplification conditions included a $15 \mu \mathrm{L}$ of reaction mix containing $0.3 \mu \mathrm{L}$ of DNA template $(2 \mathrm{ng}$ ), $0.10 \mathrm{mM}$ each deoxynucleotide triphosphate, $3 \mu \mathrm{L}$ of $1 \times$ buffer (Taq DNA Polymerase, Bioline ${ }^{\circledR}$, Eveleigh, New South Wales, Australia), $0.3 \mathrm{mM}$ of each of forward and reverse primer and 1U Taq DNA Polymerase (Bioline ${ }^{\circledR}$, Eveleigh, New South Wales, Australia). The PCR conditions consisted of an initial denaturation at $95^{\circ} \mathrm{C}$ for $5 \mathrm{~min} ; 35$ cycles of $30 \mathrm{~s}$ denaturation at $95^{\circ} \mathrm{C}, 30 \mathrm{~s}$ annealing at $59^{\circ} \mathrm{C}$ and extension for $2 \mathrm{~min}$ at $72^{\circ} \mathrm{C}$. Products $(7 \mu \mathrm{l})$ were visualised on ethidium bromide-stained $1.5 \%(\mathrm{w} / \mathrm{v})$ agarose gels. The specificity of the primers was tested against DNA templates of S. tanaceti (UMSt5 TAS 1, UMSt6 TAS 55503), the other 14 Stagonosporopsis species listed in Table 1 and eight foliar fungal pathogens of pyrethrum listed above.

\section{TaqMan PCR assay}

All TaqMan PCR analyses were carried out using a Bio-Rad ICycler (Bio-Rad Laboratories, Hercules, CA, USA) real-time PCR system. Each DNA sample of 25 fungal isolates was loaded in triplicate in a total volume of $20 \mu \mathrm{L}$ per sample, which included $10 \mu \mathrm{L}$ master mix (TF, 2X-TaqMan Fast Universal PCR Master, Life Technologies Australia Pty Ltd. (Mulgrave, Victoria, Australia), $0.3 \mu \mathrm{L}$ of each primer $(0.1 \mu \mathrm{M}), 0.4 \mu \mathrm{L}$ of TaqMan probe (5 $\mu$ M) (TaqMan MGB probe- 6000 PMoles, Life Technologies Australia Pty Ltd., Mulgrave, Victoria), $3 \mu \mathrm{L}$ of genomic DNA and $6 \mu \mathrm{L}$ of nuclease free water. Each series of amplification reactions included a negative control consisting of only sterile deionized MQ water to test for contamination. Thermal cycling conditions included a holding stage for 2 min at $50^{\circ} \mathrm{C}$ and $20 \mathrm{~s}$ at $95^{\circ} \mathrm{C}$, followed by 40 cycles of amplification at $95^{\circ} \mathrm{C}$ for $1 \mathrm{~s}$, and then at $60^{\circ} \mathrm{C}$ for $20 \mathrm{~s}$. Data were collected and analysed using Minitab (v. 16; State College, PA, Minitab Inc.) software.

\section{Specificity testing}


A suitable primer pair specific only to $S$. tanaceti was selected for preliminary conventional PCR assays. Then the selected primers and probes were tested for their specificity against the IGS region (KP161044) using $1 \mathrm{ng} / \mu \mathrm{L}$ of genomic DNA from 14 Stagonosporosis isolates obtained from CBS (Table 1), three isolates of S. tanaceti (UMSt5 , UMSt6 and UMSt 1) and eight foliar fungi Alternaria infectoria (UMAi01 BRIP65180), Stemphylium herbarum (UMSh02 BRIP65181), Colletotrichum tanaceti (BRIP57314), Didymella tanaceti (UMDt 1), Pestalotiopsis sp. (UMPes 1), Paraphoma vinacea (UMPv001 BRIP63684), Pa. chlamydocopiosa (UMPco1 BRIP65168) and Pa. pye (UMPp02 BRIP65169) followed by the TaqMan PCR assay. The $\mathrm{C}_{\mathrm{t}}$ value $>2$ cycles below the smallest standard or no amplification of any product were considered as no detection.

\section{Sensitivity testing}

The sensitivity and amplification efficiency for the IGS region of $S$. tanaceti was assessed based on the slope of a regression standard curve constructed from the amplification of 10fold dilution series of template DNA of $S$. tanaceti $(10 \mathrm{ng}, 1 \mathrm{ng}, 100 \mathrm{pg}, 10 \mathrm{pg}, 1 \mathrm{pg}, 100 \mathrm{fg}$, $10 \mathrm{fg}$ and $1 \mathrm{fg}$ ). The reproducibility of the standard curve was assessed by calculating the standard deviation of triplicate reactions in the 96-well plates.

\section{Detection and quantification of $S$. tanaceti in seed lots from farmer's fields}

Incidence of $S$. tanaceti infection (\%) in seed lots from farmer's fields using agar plate culturing

A total of 32 seed samples were collected from seed lots made up from four pyrethrum cultivars (BR1, BR2, RS5 and Pyper) from four farms (site code: 30730, 30734, 30702 and 30724) of Botanical Resources Australia - Agricultural Services Pty Ltd. (BRA) located at Forth and Kindred in North West Tasmania in the years 2014 and 2015. One hundred seeds 
from each sample were randomly collected then plated separately onto water agar (WA) in 90-mm Petri plates using $10 \mathrm{seed} /$ plate and incubated at $25^{\circ} \mathrm{C}$ under $12 \mathrm{~h}$ of alternating dark and light for 7 days. This process was repeated four times for each seed sample. This experiment was performed in a completely randomised design. Stagonosporopsis tanaceti infected seed were identified by observing the mycelial characteristics that developed on WA as described by Bhuiyan et al. (2017b). The incidence of $S$. tanaceti infected seed was calculated using the formula of Bhuiyan et al. (2017b). The difference within the replicates of each seed sample was analysed using a generalised linear model with standard error using IBM SPSS Statistics 22 software.

DNA extraction from seed samples and TaqMan assay

One hundred seeds ( 129 mg) from each of 24 seed samples were ground into a fine powder by using a mortar and pestle and liquid nitrogen. Extraction of DNA was performed using the DNeasy Plant Mini Kit (Qiagen, Hilden, Germany) following the manufacturer's guidelines. The concentration of DNA was adjusted to a dilution of $10 \mathrm{ng} / \mu \mathrm{L}$ using a NanoDrop 2000 spectrophotometer (Thermo Scientific ${ }^{\circledR}$, Scoresby, Victoria, Australia). This process was repeated three times for each sample. Three $\mu \mathrm{L}$ of the extracted DNA from 24 seed samples was tested with TaqMan PCR assays which were conducted in triplicate. A positive control using genomic DNA of $S$. tanaceti and sterile deionized MQ water as the negative control were included. Linear regression analysis was used to analyse the relationship between the seed infection (\%) and cyclic threshold of $S$. tanaceti DNA in pyrethrum seed.

\section{Detection and quantification of $S$. tanaceti in pyrethrum seedlings}

A total of 200 seeds of BR1-30730-15 were collected from Forth, North West Tasmania; a leading pyrethrum growing area in Australia with a history of infection from ray blight. Seeds were sown in a potting mix (Debco seed and cutting mix, Bella Vista, New South Wales, 
Australia) on a tray $(30 \times 35 \mathrm{~cm})$ and then grown in a glasshouse with a $12 \mathrm{~h}$ alternating light/dark at $25^{\circ} / 20^{\circ} \mathrm{C}$ in day/night. The tray was watered once per day with $150 \mathrm{~mL}$ of water using a sprinkler system. After 3 weeks, 10 seedlings $(\sim 150 \mathrm{mg})$ that were free from any visible disease symptoms were randomly collected, washed with sterile distilled water to remove soil and then dried in a laminar flow cabinet. DNA was extracted from those seedlings using the CTAB method of Clarke (2009). This process was repeated three times. DNA concentration was adjusted using a NanoDrop 2000 spectrophotometer (Thermo Scientific $^{\circledR}$, Scoresby, Victoria, Australia) to a dilution of $10 \mathrm{ng} / \mu \mathrm{L}$ for use in TaqMan PCR assay.

Three $\mu \mathrm{L}$ of the extracted DNA from three seedling samples was tested with TaqMan PCR assays which was conducted in duplicate. A positive control using genomic DNA of $S$. tanaceti and sterile deionized MQ water as the negative control were included. The detection and quantification of genomic DNA of $S$. tanaceti in each seedling sample was determined based on the $C_{t}$ value corresponding to the standard value generated from the sensitivity testing.

\section{Results}

\section{Selection of PCR primers}

All nine primer pairs successfully amplified DNA obtained from pure culture of $S$. tanaceti without any primer dimer formation in the conventional PCR assay. The PCR products on $1.5 \%$ agarose gel for primer pair $\mathrm{St}+\mathrm{qF} 3 / \mathrm{St}$-qR2 were more intense than those of the other primer pairs. Therefore, that oligonucleotides primer pair was selected for the assessment of TaqMan PCR assays.

Specificity testing of primer pair St_qF3/ St_qR2 against Stagonosporopsis species 
Using conventional PCR, the primer pair St_qF3, St_qR2 repeatedly and reliably amplified a $125 \mathrm{bp}$ DNA fragment from the IGS region of nrDNA of $S$. tanaceti, isolates UMSt5 TAS 1 and UMSt6 TAS 55503, but did not amplify sequences from the closely related ray blight pathogens of chrysanthemum S. chrysanthemi and $S$. inoxydabilis, or 12 related Stagonosporopsis species (Fig. 1) and other foliar fungal pathogens of pyrethrum (data not presented).

Using TaqMan PCR assay, the combination of primers (St_qF3, St_qR2) and probe (St_q P) consistently amplified a 125-bp product from the IGS region of $S$. tanaceti (UMSt5 TAS 1, UMSt6 TAS 55503 and UMSt 1), but failed to generate an amplicon from any of 14 Stagonosporopsis species tested including the closely related $S$. chrysanthemi and $S$. inoxydabilis and eight foliar fungal pathogens (A. infectoria, St. herbarum, C. tanaceti, D. tanaceti, Pestalotiopsis sp., Pa. vinacea, Pa. chlamydocopiosa and Pa. pye) of pyrethrum.

\section{Sensitivity testing of the TaqMan PCR assay}

In the sensitivity assay using primer-probe (St_qF3/St_qR2 and St_q P) in the ten-fold dilution series of $S$. tanaceti DNA, the upper and lower limit for quantification of target DNA was between $10 \mathrm{ng}$ and $100 \mathrm{fg}$ with $\mathrm{C}_{\mathrm{t}}$ values of 17.59 and 36.34 respectively (Fig. 2). Samples yielding a $C_{t}$ value $\leq 36.34$ were counted as positive. The standard curve between the DNA concentrations expressed as $\log (q)$ and $\mathrm{C}_{\mathrm{t}}$ value produced a linear fit with a slope of -3.667 , linear regression coefficient $\left(R^{2}\right)$ of 0.997 and the PCR efficiency was $87.3 \%$. The linearity was lost and the $R^{2}$ value was decreased if the samples were included with the quantity of genomic DNA above or below the range $10 \mathrm{ng}$ to $100 \mathrm{fg}$.

\section{Detection and quantification of $S$. tanaceti in pyrethrum seed lots}


The conventional assay showed that only five out of 32 seed samples $(15.6 \%)$ were infected with $S$. tanaceti with 1 to $30.5 \%$ infection levels (Table 3 ). The others were free from $S$. tanaceti infection in both culture and TaqMan PCR assays.

There was a significantly negative correlation between infection level of $S$. tanaceti and the $\mathrm{C}_{\mathrm{t}}$ values $(\mathrm{r}=-0.999, P<0.001)($ Fig. 3$)$. The highest $\mathrm{C}_{\mathrm{t}}$ value $(33.60)$ was obtained from $1 \%$ S. tanaceti infected seed sample and the lowest $\mathrm{C}_{\mathrm{t}}$ value (24.72) was obtained from $30.5 \% \mathrm{~S}$. tanaceti infected seed lot.

\section{Detection and quantification of $S$. tanaceti in pyrethrum seedlings}

Symptomless infected seedlings were detected in two out of three samples where the quantity of genomic DNA of $S$. tanaceti was between $~ 540$ fg to $1 \mathrm{pg}$ (Table 4).

\section{Discussion}

The primer pair St_qF3/ St_qR2 developed from the IGS region of genomic DNA of $S$. tanaceti was highly specific for detecting the DNA of $S$. tanaceti and did not amplify DNA of 14 closely related Stagonosporopsis species using conventional PCR assay. In addition, the same primer pair and probe St_qP in the TaqMan PCR assay only amplified DNA of $S$. tanaceti but not the other 14 related Stagonosporopsis species or other foliar fungal pathogens of pyrethrum.

The sensitivity limit (10 ng to $100 \mathrm{fg}$ of fungal DNA) of detection of $S$. tanaceti DNA in the TaqMan assay was higher than the previous conventional PCR detection limit ( $800 \mathrm{fg}$ of fungal DNA) reported by Pethybridge et al. (2006). In addition, this was the first attempt to quantify genomic DNA using the IGS sequence where the detection and quantification ranged between $10 \mathrm{ng}$ to $100 \mathrm{fg}$ with $\mathrm{C}_{\mathrm{t}}$ threshold values of 17.59 and 36.34 , respectively. Infected pyrethrum seed did not produce any visual symptoms of infection thus making 
diagnosis of the pathogen difficult (Bhuiyan et al. 2017b). This TaqMan PCR assay enabled the assessment of latent infection and quantified the infection level in commercial seed lots. There was a negative correlation between the infection level in seed lots and cyclic threshold of TaqMan assay. Correct estimation of infection level within the seed lot is important because seed is a major source of $S$. tanaceti in the field, which contributes to ray blight epidemics (Pethybridge et al. 2005). According to Pethybridge et al. (2006) a level of $S$. tanaceti infection in commercial seed lot above $28 \%$ may lead to the development of ray blight epidemics in the field. In addition, environmental factors such as warm and wet conditions favour the development of ray blight epidemics in chrysanthemum (McCoy 1973).

For the first time, S. tanaceti infection was detected and quantified within symptomless seedlings using the TaqMan PCR assay. Bhuiyan et al. (2017b) reported that about 7\% of the seedlings from seed lots containing 30 to $35 \%$ infection with $S$. tanaceti, were infected without showing any visible symptoms. Transmission of $S$. tanaceti infection from pyrethrum seed-to-seedling where seedlings remained asymptomatic was also reported by Pethybridge et al. (2008b).

This TaqMan PCR assay will enable quick detection of $S$. tanaceti and will help to assess the infection level within the seed and seedlings which is essential for effective seed treatments. This assay may also be used to detect the latent infection in planta as the disease develops during different growth stages of the pyrethrum plants.

\section{Acknowledgements:}

This project was supported by Botanical Resources Australia (BRA)-Agricultural Services Pty. Ltd.

\section{Compliance with Ethical Standards:}


This research does not contain any conflicts of interest, nor research involving humans or animals.

\section{References}

Bhuiyan, M.A.H.B., Groom, T., Nicolas, M.E., \& Taylor, P.W.J. (2015). Histopathology of S. tanaceti infection in pyrethrum leaf lamina. Australasian Plant Pathology, 44(6), 629-636.

Bhuiyan, M.A.H.B., Groom, T., Nicolas, M.E., \& Taylor, P.W.J. (2017a). Disease cycle of Stagonosporopsis tanaceti in pyrethrum plants. Australasian Plant Pathology, 46(1), $83-90$.

Bhuiyan, M.A.H.B., Groom, T., Nicolas, M.E., \& Taylor, P.W.J. (2017b). Infection process of S. tanaceti in pyrethrum seeds and seedlings. Plant Pathology, 66(5), 743-751.

Chilvers, M.I., du Toit, L.J., Akamatsu, H. \& Peever, T.L. (2007) A real-time, quantitative PCR seed assay for Botrytis spp. that cause neck rot of onion. Plant Disease, 91(5), 599-608.

Clarke, J.D., (2009). Cetyltrimethyl ammonium bromide (CTAB) DNA miniprep for plant DNA isolation. Cold Spring Harbor Protocols, 2009(3), 5177-5178.

De Gruyter, J., van Gent-Pelzer, M. P., Woudenberg, J. H., van Rijswick, P. C., Meekes, E. T., Crous, P. W., \& Bonants, P. J. (2012). The development of a validated real-time (TaqMan) PCR for detection of Stagonosporopsis andigena and S. crystalliniformis in infected leaves of potato and tomato. European Journal of Plant Pathology, 134(2), 301-313.

Hillis, D. M., \& Dixon, M. T. (1991). Ribosomal DNA: molecular evolution and phylogenetic inference. The Quarterly Review of Biology, 66(4), 411-453. 
Liew, E. C. Y., Maclean, D. J., \& Irwin, J. A. G. (1998). Specific PCR based detection of Phytophthora medicaginis using the intergenic spacer region of the ribosomal DNA. Mycological Research, 102(1), 73-80.

Luo, G., \& Mitchell, T. G. (2002). Rapid identification of pathogenic fungi directly from cultures by using multiplex PCR. Journal of Clinical Microbiology, 40(8), 28602865.

Mancini, V., Murolo, S., \& Romanazzi, G. (2016). Diagnostic methods for detecting fungal pathogens on vegetable seeds. Plant Pathology. 65(5), 691-703.

McCoy, R. E. (1973). Ballistics of Mycosphaerella ligulicola ascospore discharge. Phytopathology 63 (6), 793.

Pethybridge, S. J., Esker, P., Hay, F., Wilson, C., \& Nutter Jr, F. W. (2005). Spatiotemporal description of epidemics caused by Phoma ligulicola in Tasmanian pyrethrum fields. Phytopathology, 95(6), 648-658.

Pethybridge, S. J., Hay, F. S., Clarkson, R. A., Groom, T., \& Wilson, C. R. (2008a). Host range of Australian Phoma ligulicola var. inoxydablis isolates from pyrethrum. Journal of Phytopathology, 156(7-8), 506-508.

Pethybridge, S. J., Hay, F. S., Esker, P. D., Gent, D. H., Wilson, C. R., Groom, T., \& Nutter Jr, F. W. (2008b). Diseases of pyrethrum in Tasmania: challenges and prospects for management. Plant Disease, 92(9), 1260-1272.

Pethybridge, S. J., Hay, F., Jones, S., Wilson, C., \& Groom, T. (2006). Seedborne infection of pyrethrum by Phoma ligulicola. Plant Disease, 90(7), 891-897.

Rozen, S., \& Skaletsky, H. (1999). Primer3 on the WWW for general users and for biologist programmers. Bioinformatics Methods and Protocols, 365-386. 
Tomlinson, J. A., Boonham, N., Hughes, K. J. D., Griffin, R. L., \& Barker, I. (2005). On-site DNA extraction and real-time PCR for detection of Phytophthora ramorum in the field. Applied and Environmental Microbiology, 71(11), 6702-6710.

Vaghefi, N., Hay, F. S., Pethybridge, S. J., Ford, R., \& Taylor, P. W. J. (2016a). Development of a multiplex PCR diagnostic assay for the detection of Stagonosporopsis species associated with ray blight of Asteraceae. European Journal of Plant Pathology, 146(3), 581-595.

Vaghefi, N., Pethybridge, S. J., Ford, R., Nicolas, M. E., Crous, P. W., \& Taylor, P. W. J. (2012). Stagonosporopsis spp. associated with ray blight disease of Asteraceae. Australasian Plant Pathology, 41(6), 675-686.

Vaghefi, N., Pethybridge, S. J., Hay, F. S., Ford, R., Nicolas, M. E., \& Taylor, P. W. J. (2016b). Revisiting Stagonosporopsis species associated with chrysanthemum and pyrethrum ray blight. Australasian Plant Pathology, 45(6), 561-570.

Ward, E., Foster, S. J., Fraaije, B. A., \& McCartney, H. A. (2004). Plant pathogen diagnostics: immunological and nucleic acid-based approaches. Annals of Applied Biology, 145(1), 1-16. 


\section{Figures with legends}

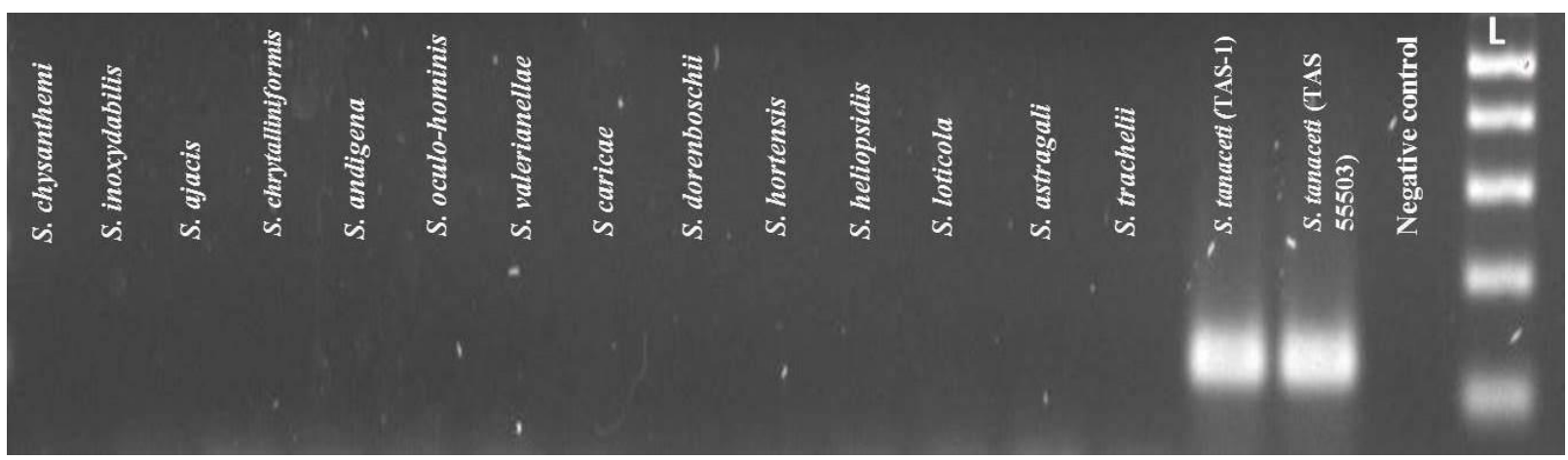

Figure 1. Specificity testing of $S$. tanaceti using conventional PCR assay. Primer pair (St_qF3/St_qR2) only amplified S. tanaceti (approximately 125 bp amplicon), compared to 14 related Stagonosporopsis species; L=100-pb DNA ladder marker (New England BioLabs Inc., Ipswich, MA, USA). Uppermost band $=500 \mathrm{bp}$ and lowermost band $=100 \mathrm{bp}$.

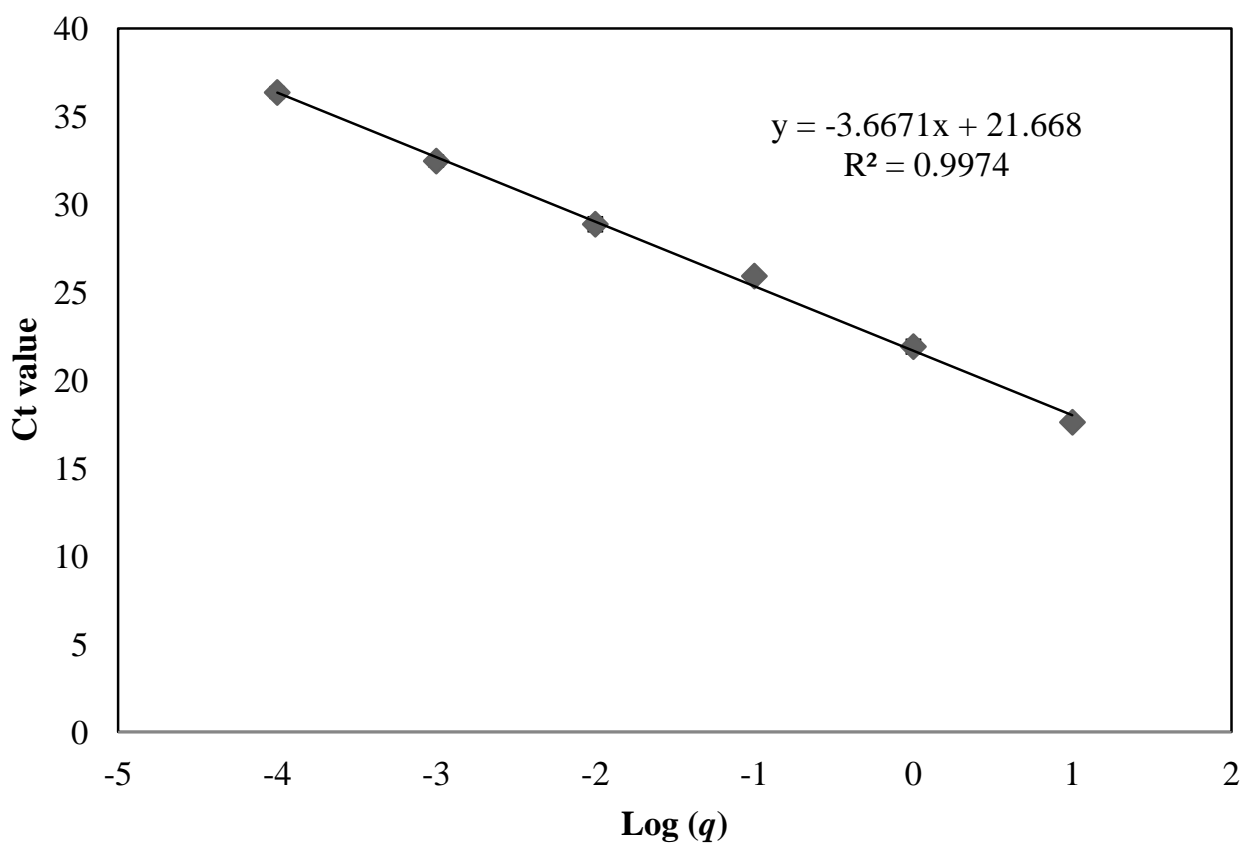

Figure 2. Standard regression line of the 10-fold serial dilution of $S$. tanaceti genomic DNA in a TaqMan assay. Threshold cycles $\left(\mathrm{C}_{\mathrm{t}}\right)$ were plotted in $\mathrm{Y}$-axis against the log of genomic DNA standards of known concentrations $(q)$ plotted in X-axis. Data represented mean of triplicate of a known DNA concentration; bars represent the standard deviation of a mean. 


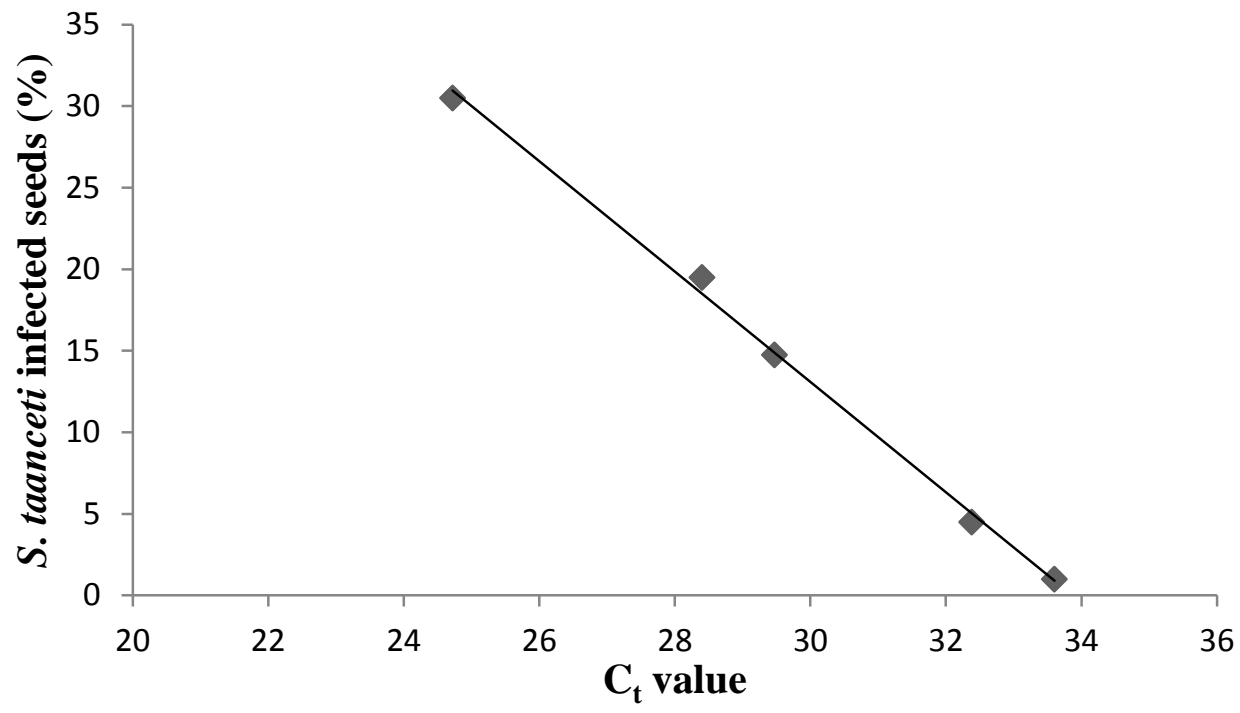

Figure 3. Correlation between infection level of $S$. tanaceti (\%) and $\mathrm{C}_{\mathrm{t}}$ value in TaqMan PCR assay $(\mathrm{r}=-0.999 ; P<0.001)$.

Table 1: Isolates used for the validation of diagnostic assay specificity

\begin{tabular}{|l|l|l|l|}
\hline Species & Strain number & Substrate & Country \\
\hline S. tanaceti & UMSt5 TAS 1, & Tanacetum & Australia \\
& 55503 & TASt6rariifolium & \\
\hline S. chrysanthemi & CBS 500.63 & Chrysanthemum & Netherlands \\
\hline S. inoxydabilis & CBS 425.90 & C. parthenii & \\
\hline S. ajacis & CBS 177.93 & Delphinium sp. & Netherlands \\
\hline S. chrytalliniformis & CBS 713.85 & Lycopersicon esculentum & Columbia \\
\hline S. andigena & CBS 101.80 & Solanum sp. & Peru \\
\hline S. oculo-hominis & CBS 634.92 & Human & USA \\
\hline
\end{tabular}




\begin{tabular}{|l|l|l|l|}
\hline S. valerianellae & CBS 329.67 & Valerianella locusta var. & Netherlands \\
\hline S. caricae & CBS 248.90 & Carica papaya & Chile \\
\hline S. dorenboschii & CBS 426.90 & Physostegia virginiana & Netherlands \\
\hline S. hortensis & CBS 104.42 & Unknown & Netherlands \\
\hline S. heliopsidis & CBS 109182 & Heliopsis patula & Netherlands \\
\hline S. loticola & CBS 562.81 & Lotus pedunculatus & New Zealand \\
\hline S. astragali & CBS 178.25 & Astragalus sp. & Unknown \\
\hline S. trachelii & CBS 379.9 & Campanula isophylla & Netherlands \\
\hline
\end{tabular}

Table 2. Designations, sequences and expected product sizes of oligonucleotide primers (forward and reverse) and a oligonucleotide TaqMan probe

\begin{tabular}{|c|c|c|c|}
\hline $\begin{array}{l}\text { Set } \\
\text { number }\end{array}$ & Primer/ Probe & Sequence $\left(5^{\prime}\right.$ to $\left.3^{\prime}\right)$ & $\begin{array}{l}\text { Expected } \\
\text { product (bp) }\end{array}$ \\
\hline i. & $\begin{array}{l}\text { St_q F1 (forward primer) } \\
\text { St_q R1 (reverse primer) }\end{array}$ & $\begin{array}{l}\text { ATTCCCCCTAAAGGTGAGG } \\
\text { AGTACCTGCCGAAGCTGA }\end{array}$ & 112 \\
\hline ii. & $\begin{array}{l}\text { St_q F2 (forward primer) } \\
\text { St_q R2 (reverse primer) }\end{array}$ & $\begin{array}{l}\text { CCCTAAAGGTGAGGGTAGG } \\
\text { GAGCTTTTGGGCAGTACCT }\end{array}$ & 119 \\
\hline iii. & $\begin{array}{l}\text { St_q F3 (forward primer) } \\
\text { St_q R3 (reverse primer) }\end{array}$ & $\begin{array}{l}\text { CATTCCCCCTAAAGGTGAG } \\
\text { ССССТАACTCTAGGCGGTAT }\end{array}$ & 85 \\
\hline iv. & $\begin{array}{l}\text { St_q F1 (forward primer) } \\
\text { St_q R2 (reverse primer) }\end{array}$ & $\begin{array}{l}\text { ATTCCCCCTAAAGGTGAGG } \\
\text { CCСTAAAGGTGAGGGTAGG }\end{array}$ & 124 \\
\hline v. & St_q F1 (forward primer) & ATTCCCCCTAAAGGTGAGG & 84 \\
\hline
\end{tabular}




\begin{tabular}{|l|l|l|l|}
\hline vi. & St_q R3 (reverse primer) & CCCCTAACTCTAGGCGGTAT & \\
& St_q F2 (forward primer) & CCCTAAAGGTGAGGGTAGG & 107 \\
\hline vii. & St_q F2 (forward primer) & CCCTAAAGGTGAGGGTAGG & 79 \\
\hline viii. & St_q R3 (reverse primer) & CCCCTAACTCTAGGCGGTAT & \\
\hline ix. & St_q F1 (forward primer) & CATTCCCCCTAAAGGTGAG & 113 \\
& St_q F3 (forward primer) & CATTCCCCCTAAAGGTGAG & 125 \\
\hline & St_q P (TaqMan probe) & CCTAGCTTAGGGGCTCGACT & \\
\hline
\end{tabular}

Table 3. Estimation of level of infection with S. tanaceti (\%) in pyrethrum seed using traditional culture and TaqMan PCR assays.

\begin{tabular}{|c|c|c|}
\hline $\begin{array}{l}\text { Pyrethrum seed (cultivar- } \\
\text { site-year) }\end{array}$ & $\begin{array}{l}{ }^{\text {a}} \text { Estimated infection level of } \\
\text { S. tanaceti (\%) using } \\
\text { culture assay }\end{array}$ & ${ }^{\mathrm{b}} \mathrm{C}_{\mathrm{t}}$ value $(\mathrm{SE}){ }^{\dagger} ; P<0.001$ \\
\hline BR1-30730-15 & $30.5(1.06)$ & $24.72(0.14)$ \\
\hline RS5-30734-15 & $19.5(0.54)$ & $28.40(0.18)$ \\
\hline BR2-30702-14 & $14.7(1.10)$ & $29.47(0.10)$ \\
\hline BR2-30730-14 & $4.5(0.45)$ & $32.38(0.09)$ \\
\hline Pyper-30724-14 & $1.0(0.40)$ & $33.60(0.18)$ \\
\hline \multicolumn{3}{|c|}{$\begin{array}{l}{ }^{a} \text { Values represent arithmetic mean }(n=4) \text {, values within the parenthesis are standarc } \\
\text { error; }{ }^{b} \text { Values represent arithmetic mean }(n=9),{ }^{\dagger} \text { Standard error }(\mathrm{SE}) \text {. }\end{array}$} \\
\hline
\end{tabular}


Table 4. $C_{t}$ values of TaqMan PCR determined in duplicate of seedlings

\begin{tabular}{|c|c|c|}
\hline Replication & $\mathrm{C}_{\mathrm{t}}$ values against genomic DNA of $S$. tanaceti on asymptomatic seedlings \\
\hline 1 & 33.62 & 32.45 \\
\hline 2 & 33.56 & 32.65 \\
\hline 3 & nd & nd \\
\hline
\end{tabular}

nd $=$ not detected 